\title{
In Search of Concepts: The Effects of Speculative Demand on Stock Returns
}

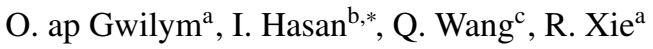 \\ ${ }^{a}$ Bangor Business School, Hen Goleg, College Road, Bangor LL57 2DG, United Kingdom. \\ ${ }^{b}$ Fordham University, 1790 Broadway, 11th Floor, New York, NY 10019, and Bank of Finland \\ ${ }^{c}$ Cardiff Business School, Aberconway Building, Colum Drive, Cardiff, CF10 3EU, United Kingdom.
}

\begin{abstract}
Using a novel proxy of investors' speculative demand constructed from online search interest in investment concepts, we examine how speculative demand affects the returns of Chinese stocks. We find that speculative demand increases following high market returns and predicts subsequent return reversals. Moreover, the speculative demand explains more variation in subsequent returns of A shares (more populated by retail investors) than B shares (less populated by retail investors). Our findings support the attention theory of Barber and Odean (2008).

Keywords: Investment Concepts, Speculative Demand, Investor Attention, Market Returns, Trading Volume

JEL: G02, G12, G14
\end{abstract}

\footnotetext{
We thank Franklin Allen, Chunxin Jia (discussant), Nancy Qian, Jianhua Xie, Wei Xiong, and seminar participants at the Princeton University \& Peking University Symposium on China's Financial Markets for helpful discussions. We also thank Yizheng Wang for his excellent research assistance. Errors and omissions remain the responsibility of the authors.

*Corresponding author.

Email addresses: owain. apgwilym@bangor.ac.uk (O. ap Gwilym), ihasan@fordham.edu (I. Hasan), wangq30@cardiff.ac.uk (Q. Wang), r.xie@bangor.ac.uk (R. Xie)
} 


\section{Introduction}

Recent studies show that individual investors tend to speculate in the stock markets and hold stocks with lottery features (Kumar (2009), Dorn and Huberman (2010) and Han and Kumar (2013)). For their speculation to have a significant impact on stock returns, individual investors must trade on the same stocks at about the same time (Barber, Odean and Zhu (2009)). However, there are thousands of stocks in the market. Upon which one(s) should they speculate? Froot, Scharfstein and Stein (1992) show that short-horizon speculators will attempt to learn what other speculators also know. If we can track such efforts, we can measure speculators' willingness to speculate and examine its effect on asset prices. Such a measure is difficult to identify because those efforts are typically not observable.

We propose a novel measure based on individual investors' online search for investment ideas and concepts. Arguably, investment "concepts" or "ideas" provide ideal information for speculators to herd on, which may explain why speculative bubbles often start with the emergence of investment concepts such as dot-coms during the internet bubble. When such information is publicly available online, individual investors can simply use search engines. Knowing that others can find similar information online, investors know what they can herd. Google provides a search volume index to track search intensity on certain keywords over a defined period relative to the total number of searches during that period. Da, Engelberg and Gao (2011) provide evidence that individual investors are more likely to use Google to search for information than are professional investors. Therefore the search volume index on the keywords related to investment "concepts" and "ideas" may reveal individual investors' interest in speculation.

Using a measure of investors' speculative demand constructed from the search volume index in Mainland China on the keyword "concept stocks", we examine how speculative demand affects the returns of Chinese stocks. Concept stocks, prone to speculation, typically rely on certain business and investment opportunities or the emergence of a new technology. These stocks usually have highly uncertain growth prospects and are difficult to value, which leaves more room for heterogeneous views and speculation. Concept stocks in China are linked either with certain events or industries. The events can be mega sport events, political events or major firm events (e.g. merger and acquisitions). For example, the 2008 Beijing Olympic Games were believed to benefit tourism, construction and retail businesses, therefore the stocks of related companies are classified as Olympic-concept stocks. The Dot-com industry and new energy industry are two further examples related to concept stocks. Once the companies are classified as concept stocks, they attract substantial investor attention and can become considerably overpriced. Shanghai Maling is a frequently cited example of overpriced concept stocks related to the dot com industry in China. The company produces canned food for urban area markets. In June 1998 Shanghai Maling set up a web site for selling its own products, and was subsequently labeled as an internet concept stock. While its main business remained 
the same, the company's share price soared from 149.96 Chinese yuan on December 30, 1999 to 552.7 Chinese yuan on February 18, 2000 before tumbling 46 percent four months later. In the literature, concept stocks are related to several heated speculative episodes, including the biotechnology bubble in the 1980s and the dot-com bubble in the 1990s (Hsieh and Walkling (2006)). These authors document the history and performance of concept stocks thoroughly, revealing that concept stocks are overpriced because they underperform in the long run.

Chinese markets offer unique opportunities to better understand and investigate the impact of speculative trading using our measure. Investment ideas and concepts are routinely mentioned in the Chinese financial press and on the internet through discussing stocks related to some investment concepts. These stocks are collectively referred to as "concept stocks". For example, concept stocks are on average mentioned 20 times every day between 01.01.2004 and 24.04.2014 by the articles on the web page of China Securities Journal, a major financial newspaper in China. Additional evidence can be seen from a search of the keywords "concept stocks" (in quotes) in Chinese on Google; such a search yields 17,200,000 results. A similar search on Baidu, the most popular Chinese online search engine, yields 23,600,000 relevant results. By contrast, a similar Google search on the same keyword in English yields only 29,600 results. ${ }^{1}$ Despite lesser popularity of "concept stocks" in other countries, our approach of measuring investors' willingness to speculate can be applied in other markets, possibly through the search volume index on other speculative stocks such as "penny stocks" or keywords such as "hot stocks", "best stocks", or "stocks to buy".

This paper does not study concept stocks per se. The focus is on tracing the impact of investors' interest in these stocks. We provide empirical evidence that the search interest in "concept stocks" captures investors' willingness to speculate. ${ }^{2}$ We show that it strongly co-moves with the number of new stock accounts in the Chinese stock markets. When new investors start to speculate in the stock markets, they are more likely to have a need to identify investment concepts or ideas. Therefore we would expect that the number of new stock accounts will increase with retail investors' willingness to speculate in the stock markets. In addition, it is significantly and positively related to trading volume, a widely used measure of speculative trading. Trading volume reflects differences of opinion. When short selling is costly or forbidden, pessimistic investors choose to stay out of the market. Prices can be higher due to the demand from optimistic investors. However, trading volume can be driven by other motives such as liquidity needs, hedging demand, etc. In contrast, our measure reflects investors' willingness to speculate in the market, which is unlikely to be affected by those other trading motives.

\footnotetext{
${ }^{1}$ These searches were conducted on $15 / 02 / 2013$.

${ }^{2}$ There might be search of the keywords "concept stocks" by people other than investors. For example, a journalist may search it on Google for preparing a news article. However, their search is likely to reflect an anticipated interest of investors in concept stocks and their news article could attract further attention of investors.
} 
To determine an unambiguous prediction of an increase in the search intensity of concept stocks on stock returns, we need to know which price pressure it generates: buying or selling pressure. We argue that Chinese investors' search interest in concept stocks leads to buying pressure. First, individual investors face a formidable search problem in deciding which stocks to trade among thousands. The search problem is more severe when buying stocks than it is when selling (Barber and Odean (2008)), implying that search activities are much more likely to be related to buying interest. Investors need to select from thousands of stocks when buying, but once they hold stocks and consider selling, they only need to consider the subset of those stocks that they already hold. This is particularly true for retail investors because they hold fewer stocks and are much less likely to short sell stocks. In contrast, institutional investors hold much larger stock portfolios and hence face a search problem when selling stocks too. This is especially the case when they want to short sell, since they need to search for which stocks to short sell. Second, individual investors are more likely to acquire financial information through internet searches e.g. via Google. Therefore the Google search volume index of "concept stocks" should reflect Chinese retail investors' speculative demand. Third, China has stringent short sales constraints, ${ }^{3}$ which makes short selling unrealistic. Therefore online search of concept stocks is unlikely to reflect interest in short selling these stocks.

Using our novel proxy of retail investors' speculative demand, we test several hypotheses that are closely related to the "theory of attention" in Barber and Odean (2008). Firstly, Barber and Odean (2008) predict that individual investors are net buyers of attention-grabbing individual stocks. ${ }^{4}$ We argue that high market returns are more likely to capture the attention of retail investors, especially for those potential retail investors who are not yet present in the market. These investors are mostly trend chasers. In principle, their attention can be captured by both high and low market returns. However, when market returns are high, these investors are more likely to speculate in stock markets, and when market returns are low, they have few stocks to sell, and are unlikely to short sell due to short sales constraints. Therefore it is much more plausible for them to pay attention to an increase in market returns. We expect that high past returns are related to an increased willingness to speculate. Secondly, in the presence of limits to arbitrage, increased speculative demand leads to temporary overpricing, subsequent returns decline as speculative demand wanes and fundamentals are revealed. ${ }^{5}$ Thirdly, the search interest in concept stocks plays a stronger role for predicting the subsequent returns of constituents of Chinese A Shares indices than for the constituents of B Shares indices. This is due

\footnotetext{
${ }^{3}$ On March 31, 2010, the China Securities Regulatory Commission (CSRC) permitted short selling of 90 securities by six pilot securities dealers for the first time. However, the short sales activity remains negligible (Sharif, Anderson and Marshall (2014)) Similarly, Deng, Gao and Jiang (2014) report that the total trading volume of short selling accounts for less than $1 \%$ of the total stock trading volume up to Dec. 2012.

${ }^{4}$ Bae and Wang (2012) show that when a stock market boom in China captures the attention of investors, stocks listed on U.S. stock exchanges with the word "China" or "Chinese" included in their company names outperform others, consistent with the prediction of Barber and Odean (2008).

${ }^{5}$ In our empirical test, we find that contemporaneous returns are high when speculative demand is high, consistent with the prediction of overpricing due to price pressure. Such a contemporaneous correlation is admittedly subject to endogeneity issues. Therefore we focus our empirical tests on return predictability.
} 
to the fact that A-share markets are more populated by individual investors than are B-share markets.

We document empirical evidence supporting each of these hypotheses from time-series analysis of market returns and speculative demand. We also provide some evidence that speculative demand predicts return reversals in the cross-section. More concretely, we find that increased speculative demand predicts a lower subsequent small stock premium, consistent with Lemmon and Portniaguina (2006) and Baker and Wurgler (2006). This can be explained by the fact that relative to large stocks, small stocks are predominantly held by retail investors, more difficult to value and harder to arbitrage. Therefore the effect of speculative demand is larger on small stocks than large stocks. Our results provide strong support for the attention theory of Barber and Odean (2008).

The remainder of the paper is organized as follows. Section 2 reviews the relevant literature. Section 3 describes and summarizes our data set. Section 4 provides evidence that the search volume index of "concept stocks" captures investors' speculative demand. Our empirical results are provided in Section 5. Section 6 concludes.

\section{Related Literature}

As argued in the previous section, search interest in "concept stocks" can capture individual investors' speculative demand. Can individual investors move the market? If individual investors' aggregate demand is random, it should have no predictable and persistent influence on stock prices (Kyle (1985)). However, when their erroneous demand is unpredictable and systematic, noise trader risk limits the arbitrage process and influences stock returns (De Long, Shleifer, Summers and Waldman (1990)). Limits to arbitrage such as short selling constraints can prevent sophisticated investors from eliminating mispricing (Gromb and Vayanos (2010)). Baker and Wurgler (2006) and Lemmon and Portniaguina (2006) show that small stocks (that are more disproportionately held by individual investors) are more likely to be affected by sentiment. Barber, Odean and Zhu (2009) show that retail trades are correlated and move the market. Kumar (2007) shows that the diversification choices of individual investors influence stock returns. Kaniel, Saar and Titman (2008) document positive excess returns in the month following intense buying by individuals and negative excess returns after individuals sell. Bloomfield, O'Hara and Saar (2009) find that noise traders increase market volume and depth in a laboratory market.

Using Google search volume index links our paper to a growing literature on the relationship between investor attention and asset prices. In an information abundant environment such as financial markets, attention constrained investors have to allocate attention across different assets before portfolio selection. Recent studies show that limited attention affects asset price dynamics such as stock market volatility (Andrei and Hasler (2011)), return comovement, and return predictability (Peng and Xiong (2006), Peng, 
Xiong and Bollerslev (2007)). It also accelerates the speed of quote adjustment to information (Boulatov, Hatch, Johnson and Lei (2009)), leads to poorer investment results for pension investors (Dahlquist and Martinez (2015)) and post-earnings announcement drift (Hirshleifer, Lim and Teoh (2011)). Empirically testing the theory of attention calls for a proxy of investor attention. Traditional measures include media coverage, extreme price movement, or advertising expense. Unlike these indirect proxies of investors' passive attention, Da, Engelberg and Gao (2011) propose a direct measure of investors' active attention: the search intensity on certain assets through Google. Vlastakis and Markellos (2012) show that investor attention is positively related to stock market volatility, trading volume, and level of risk aversion. Other papers examine the usefulness of Google search volume index in explaining asset market phenomena such as stock prices around earning announcements (Drake, Roulstone and Thornock (2012)), liquidity and returns (Bank, Larch and Peter (2011)), predicting a firm's future cash flow (Da, Engelberg and Gao (2010)), and biased attention towards local stocks (Mondria and Wu (2012)). This literature examines the effect of search on either individual stocks or stock indices. Unlike them, we restrict our attention to concept stocks, the class of stocks which are related to investment concepts or ideas.

Mei, Scheinkman and Xiong (2009) examine how speculative trading affects stock prices in Chinese stock markets. Using trading volume as a measure of speculative trading, they find that it explains a sizable fraction of Chinese A-B share premia. Sun and Tong (2000) argue that the excess volatility of A-share over B-share can be attributed to speculative trading of A-shares, and find that it is related to the A-share price premium. Unlike those papers, we use the investors' online search interest as a novel proxy for investors' speculative demand. We examine whether it affects aggregate stock returns in the Chinese stock market.

\section{Data}

\subsection{Search Volume Index}

Google Insights provides a Search Volume Index computed as the portion of worldwide Google web search on certain keywords over a defined period relative to the total number of searches using Google during that period. These numbers are firstly normalized and then scaled from 0 to 100 in order to make them comparable across regions. We download weekly data spanning from 10/01/2004 to 24/12/2011 for a total of 416 weekly observations.

The phrase we use in Google Insights is "concept stocks" (in Chinese) which tracks the search intensity within mainland China. ${ }^{6}$ It reflects investors' interest in concept stocks in mainland China. We also measure

\footnotetext{
${ }^{6}$ We considered search volume indexes of several other phrases, such as "recommended stock", "bullish stock" (a phrase often mentioned in the Chinese financial media/internet), "value stock" and "growth stock". We find that they have much weaker relationships with returns and trading volume, and they do not affect the influence of "concept stocks". A synonym for "concept stocks" ("Gai Nian Gu") in Chinese is "Ti Cai Gu". However, its search volume is often too low to be reported as non-zero by Google Insights.
} 
"general demand" in stocks by obtaining a search volume index on the keyword "stock" (in Chinese) restricted to mainland China. ${ }^{7}$ To disentangle the speculative demand from the general demand and remove the seasonality, we run a linear regression of the original search volume index on "concept stocks" upon general demand and monthly dummies. We take the residual, "SVI", as our measure of speculative demand.

Table 1 presents the summary statistics of the original search volume index and our speculative demand variable. It can be seen that they have substantial time variations and leptokurtosis. The large standard deviation could raise a concern about biased estimation due to outliers, and we address this with median regressions, which are known to be robust to outliers. In untabulated unit root tests, we find that SVI contains no unit root.

[Insert Table 1 about here]

\subsection{The Chinese Stock Market}

The early 1990s saw the establishment of two domestic stock exchanges in China, the Shanghai Stock Exchange and the Shenzhen Stock Exchange. The market has been growing rapidly since then. In 2009, Chinese stock market capitalization exceeded US\$3.21 Trillion, overtaking Japan as the second largest stock market in the world. At the end of 2010, China had 2062 listed companies, and the number of stock investors was 130 million compared to 4 million in 1991.

Both exchanges issue A shares and B shares. A shares are specialized shares denominated in Renminbi. They can only be traded by Chinese citizens, except those foreign nationals who have acquired a QFII (Qualified Foreign Institutional Investor) quota. In contrast, B shares were initially available exclusively for foreign investors and are traded in foreign currencies. Since 2001, B shares can be held partially by Chinese domestic investors, though they can only trade after opening foreign currency accounts, which limits the participation of domestic investors. The number of listed shares and trading volume are much smaller in B-share markets than in A-share markets. The proportion of individual investors in A-share markets is higher than B-share markets. Figure 1 plots the ratio between the number of accounts held by retail investors and the number of accounts held by institutional investors in A-share markets (blue line) and B-Share markets (red line) from 2004 to 2012. ${ }^{8}$ It shows that the ratio is twice or three times higher in A-share markets than in B-share markets, indicating a potentially much more important role of individual investors in A-share markets.

\footnotetext{
${ }^{7}$ We thank an anonymous referee for this suggestion.

${ }^{8}$ The data are provided by China Securities Depository and Clearing Corporation Limited ("CSDCC") and can be downloaded from http://www.chinaclear.cn/main/03/0305/1344586217950.pdf
} 
[Insert Figure 1 about here]

The companies listed in the Shanghai Stock Exchange are pre-dominantly state-owned enterprises while many companies listed in the Shenzhen Stock Exchange are joint ventures. To allow for the growth of small to medium companies, Shenzhen Stock Exchange also introduced a Small and Medium Enterprises Board in May 2004. Starting with eight listed companies on its establishment, the SME board had 646 listed companies in 2011.

\subsection{Descriptive Statistics of Weekly Returns and Trading Volume}

We collect data on stock indices and trading volume from Bloomberg. The sample period for both A shares and B shares spans from 10/01/2004 to 24/12/2011. However, data on the stock index and trading volume of Shenzhen SME are only available from 01/12/2005. Due to the Gloden week holidays (the annual 7-day national holidays) in China, our final sample consists of 387 weekly observations for both A shares and B shares, and 294 weekly observations for the Shenzhen SME. We report the descriptive statistics of weekly returns and trading volume for five Chinese stock indices in Table 2. This shows that returns display high volatility and some degree of excess kurtosis during our sample periods. The trading volume in Panel $\mathrm{B}$ is in billions of Chinese yuan. Its descriptive statistics differ substantially across indices, and all have positive skewness.

\section{[Insert Table 2 about here]}

\section{A Measure of Speculative Demand}

What does the search volume index of "concept stock" measure? We argue that it captures (retail) investors' interest in speculating in stock markets. This section provides evidence in support of our measure by showing that it is significantly related to the number of new stock accounts in the Chinese stock markets.

From the China Securities Depository and Clearing Corporation Limited (“CSDCC”), we obtain weekly data of the number of new stock accounts in A-share and B-share markets. The sample period spans from January 2006 to December 2011. The increased new stock accounts come mostly from individual investors (99\%). The first row of Table 3 reports the correlation between the change in the number of new stock accounts and our speculative demand measure. The correlation coefficients are typically $20 \%$ to $30 \%$. All these correlation coefficients are statistically significantly at the $1 \%$ level. We also conduct 
regression analysis to examine the relationship between the number of new accounts and our speculative demand measure. When regressing the change of newly opened stock accounts on SVI (results untabulated), we find that the coefficients are significant and positive for A-share markets, even after controlling for lagged dependent variable and past trading volume. While the coefficients for B-share markets are positive, they are less significant than those for A-share markets.

[Insert Table 3 about here]

To shed further light on whether SVI measures speculative demand, we examine its relationship with another well-known measure of speculative trading, namely trading volume. We obtain the residual from an $\operatorname{AR}(1)$ regression of original trading volume as our measure of trading volume, and report its correlation coefficients with SVI in Table 3. All correlation coefficients are positive, and statistically significant at the $1 \%$ level except for Shenzhen B-share markets, which is not significant at the $10 \%$ level. The correlation coefficients for A-share markets are much larger than those for B-share markets. Regression analysis in Table 4 shows that the contemporaneous correlation between SVI and trading volume sustains after controlling for past returns and lagged trading volume, and the coefficients are economically and statistically larger for A-share markets than those for B-share markets.

[Insert Table 4 about here]

In summary, we find that search volume index on "concept stocks" is positively related to both the number of new accounts in the Chinese stock market and the trading volume. Therefore we use it as a measure of speculative demand. In the following section, we examine its relationship with returns.

\section{Empirical Results}

\subsection{Returns and the Speculative Demand: A First Look}

Before the regression analysis, we take a first look at how stock indices are related to the speculative demand. We plot the time series of the Shanghai A share index together with the Google search volume index on the phrase "concept stocks".

[Insert Figure 2 about here] 
Figure 2 shows strong co-movement between the speculative demand and both the Shanghai A share index and its trading volume. A similar pattern can be found in the plot for Shenzhen A share indices in Figure 3. Figures 2 and 3 also plot the speculative demand and the trading volume, which indicates that they co-move too.

[Insert Figure 3 about here]

\subsection{Time Series Predictability}

We now turn to regression analysis of returns on the speculative demand. We start with contemporaneous regressions. Untabulated results indicate that the speculative demand is positively and significantly related to contemporaneous returns, which is consistent with the idea that increased speculative demand exerts price pressure in the presence of limits to arbitrage, therefore contemporaneous returns are high. However, this finding is open to the possibility that both variables can be jointly determined. A more reliable test of the effect of speculative demand is the return predictability. Temporal increased returns due to contemporaneous price pressure reverse when speculative demand decays or the fundamental is revealed. Therefore, the focus of our empirical analysis is whether speculative demand predicts subsequent return reversal.

We start with parsimonious specifications which include past returns as the only control variables. More concretely, we first estimate a predictive regression with the following specification.

$$
\operatorname{Return}_{t}=\beta_{0}+\beta_{1} \operatorname{Return}_{t-1}+\beta_{2} \operatorname{Return}_{t-2}+\beta_{3} \operatorname{SVI}_{t-1}+\beta_{4} \operatorname{SVI}_{t-2}+\eta_{1, t}
$$

where "SVI" refers to our measure of speculative demand.

Table 5 reports OLS predictive regression results with Newey-West standard errors to control for potential serial correlation in residuals. It demonstrates that the coefficients on almost all the lagged speculative demand variables are negative. For Shanghai A (Shenzhen SME) shares, the coefficients of the second lag of speculative demand are statistically significant at the 5\% (10\%) level, and insignificant for coefficients of other lagged speculative demand. Economically, a one standard deviation increase in speculative demand predicts $-27.2 \%$ annualized returns in the second week for Shanghai A and Shenzhen A shares, and -30.4\% for Shenzhen SME shares. The economic significance of speculative demand is much smaller for B share markets. The adjusted R-squared ranges from $0 \%$ to $2 \%$. Moreover, adjusted R-squared values for A share indices are higher than those for B shares, suggesting that the speculative demand explains subsequent returns of the A share indices better than the subsequent returns of the B share indices. These results are not surprising since A-share markets are more populated by individual investors than are B-share markets. Including further lags of speculative demand yields similar results. 
[Insert Table 5 about here]

Expected returns are linked to macroeconomic variables or variables that forecast macroeconomic events (Cochrane (2001)). We therefore proceed to multivariate regressions which control for lagged macroeconomic variables. The macroeconomic variables we consider are the GDP growth, change in the inflation rate (CPI) and the change in money supply (M2). ${ }^{9}$ Table 6 shows the same sign and remarkably similar size of the lagged SVI coefficients to those in Table 5. While for Shenzhen SME shares, the coefficients of the second lag of speculative demand remain statistically significant at the $10 \%$ level, its significance declines from the $5 \%$ level to the $10 \%$ level for Shanghai A shares. Most coefficients of macroeconomic regressors are insignificant. The size and statistical significance of lagged speculative demand and the adjusted R-squared values indicate stronger predictive effects of speculative demand on subsequent A-share returns than B-share returns. In untabulated regressions, we also include the returns on the S\&P 500 index to account for the co-movement of domestic and international markets, and find similar results. In summary, the multivariate regressions with macroeconomic variables confirm the role of the speculative demand in explaining subsequent returns.

[Insert Table 6 about here]

\subsection{VAR and Causality}

Our return predictability analysis cannot establish causal effects between these variables. It can well be that an increase in returns attract the attention of investors. Barber and Odean (2008) find that individual stocks capturing the attention of retail investors are more likely to be related to buying interest. While both high and low market returns can capture the attention of retail investors, potential retail investors are likely to pay greater attention to an increase in market returns as a motive to trade in stock markets. When market returns decline, they have few stocks to sell and are unlikely to short sell (due to short sale constraints), therefore it is less worthwhile for them to pay attention to low market returns. Thus we expect that high returns capture the attention of those investors, hence raising subsequent speculative demand.

We run Vector Autoregressive Regressions (VAR) to examine this question. Specifically, we estimate a

\footnotetext{
${ }^{9}$ Data on quarterly GDP growth and monthly CPI are provided by the National Bureau of Statistics, China and data on monthly M2 are provided by the People's Bank of China. We collect information on these macroeconomic variables from Datastream.
} 
$\operatorname{VAR}(2)$ model with the following specification: ${ }^{10}$

$$
\begin{aligned}
\operatorname{SVI}_{t} & =\beta_{0}+\beta_{1} \operatorname{Return}_{t-1}+\beta_{2} \operatorname{Return}_{t-2}++\beta_{3} \operatorname{SVI}_{t-1}+\beta_{4} \mathrm{SVI}_{t-2}+\eta_{1, t} \\
\operatorname{Return}_{t} & =\lambda_{0}+\lambda_{1} \mathrm{SVI}_{t-1}+\lambda_{2} \operatorname{SVI}_{t-2}+\lambda_{3} \operatorname{Return}_{t-1}+\lambda_{4} \operatorname{Return}_{t-2}+\eta_{2, t}
\end{aligned}
$$

[Insert Table 7 about here]

Table 7 reports the results. Across all stock indices, the first two lags of the speculative demand measures are negatively related to current returns except the first lag for Shanghai B shares. The second lags of the speculative demand measures are significant for Shanghai A, Shenzhen A and Shenzhen SME indices, but are insignificant for both Shanghai B and Shenzhen B indices. Furthermore, the coefficients of the speculative demand measures of the two A-share indices are much larger than those of the two B-share indices, indicating substantial differences in their economic significance. These results are consistent with our predictive regression results and confirm our prediction that retail investors' speculative demand plays a more important role in A-share markets than in B-share markets.

Table 7 also reveals that the first lag of past returns is always positively related to current measures of the speculative demand, which are significant at the $1 \%$ level for both A-share and Shenzhen SME indices, but less significant for both B-share indices. Moreover, the coefficients of these past returns of A shares are also larger than those of B shares. Therefore, past returns have a stronger effect on the speculative demand in A-share markets than in B-share markets. The increase of the speculative demand due to higher past returns is in line with our conjecture that high market returns lead to the increased attention of retail investors and hence higher speculative demand. It is also consistent with irrational exuberance as described in Shiller (2005).

We also estimate a $\operatorname{VAR}(2)$ of the speculative demand and returns, which includes lagged macro-economic variables as exogenous variables. Table 8 shows that the results remain similar.

[Insert Table 8 about here]

\footnotetext{
${ }^{10}$ The Bayesian information criterion (BIC) selects optimal lags of one or two in most of our regressions. For the ease of tabulating the results, we report results of $\operatorname{VAR}(2)$ for all stock indices. Our results on the role of attention are maintained if we use the optimal number of lags according to BIC.
} 


\subsection{Cross-sectional Predictability}

Speculative demand can affect the cross section of stock returns when some stocks are more speculative than others, i.e., harder to value and more difficult to arbitrage (Baker and Wurgler (2006)). One example of such speculative stocks is small stocks. Small stocks are predominately held by noise traders (Lee, Shleifer and Thaler (1991), Foucault, Sraer and Thesmar (2011)) are less liquid, have financial distress risk (Chan and Chen (1991)) and high idiosyncratic risk.

In our empirical tests we focus on the small stock premium. Relying on these cross-sectional differences between small and large stocks, we are thus more likely to capture the impact of speculative demand on asset prices. Lemmon and Portniaguina (2006) and Baker and Wurgler (2006) take the same approach to study the time series relationship between investor sentiment and the small stock premium.

We hypothesize that when speculative demand is high, the prices of small stocks react more than prices of large stocks, which will reverse when speculative demand declines and/or fundamentals are revealed. Therefore we expect that high levels of our measure of speculative demand predict reversals of the small stock premium. On the other hand, concept stocks are not necessarily small stocks. For example, Olympic Games concept stocks include major airline companies such as Air China, which is among the top 50 largest companies by market capitalization (2012 year-end) listed at the Shanghai Stock Exchange. Therefore, we expect the cross-sectional predictability could be weakened due to this aspect.

We sort all listed stocks at the Shanghai Stock Exchange (and Shenzhen Stock Exchange separately) into deciles according to their total assets ${ }^{11}$ in the previous fiscal year. We then compute the equally- and value-weighted decile portfolio returns each week for the current year. We take the difference between the smallest decile portfolio returns and the largest decile portfolio returns as the small stock premium.

\section{[Insert Table 9 about here]}

Table 9 reports the results of predictive regressions of the equally-weighted small stock premium on our speculative demand measure. Results for the value-weighted small stock premium are qualitatively similar. We control for the lagged small stock premium in all regressions, and contemporaneous market returns (returns on Shanghai Composite Index or Shenzhen Composite Index) as well as macro-economic variables in models 2 and 4 (the second and fourth columns in Table 9). For both stock exchanges, the small stock

\footnotetext{
${ }^{11}$ Alternatively, we can sort on the firm's market capitalization. However, this suffers from many missing observations, which might in turn lead to a sample selection bias since information on market capitalization of small stocks is conceivably more likely to be missing than for large stocks.
} 
premium declines two weeks after an initial increase in speculative demand, and the decline is statistically significant at the $10 \%$ level in the third week for both stock exchanges, and for different model specifications. While the decline is still significant at the $10 \%$ level in the fourth week for Shanghai Stock Exchange, it is not significant for Shenzhen Stock Exchange. The economic significance of return reversal is at its highest in the third week, when a one standard deviation increase of speculative demand predicts a stock premium of about $-11 \%$ for Shanghai Stock Exchange and about $-16 \%$ for Shenzhen Stock Exchange in the third week. Including further lags of SVIs in the regressions does not change our results qualitatively.

\subsection{Additional Robustness Checks}

The Chinese stock market experienced boom and bust periods during our sample period. In particular, both A-share markets and B-share markets declined after 2007. In addition, if the search intensity of certain keywords is relatively small, Google records it to be zero. As shown in Figure 2, the search interest in "concept stocks" is sometimes zero before 2007. To address both concerns, we run sub-sample analyses for 2004-2007 and 2008-2011 as an additional robustness check. Our findings hold in both sub-samples.

Given limited investor attention, one may argue that rising concerns over the recent financial crisis may crowd out investors' interest in "concept stocks". If the former affects the stock returns and trading volume, one would expect that the latter can be (spuriously) correlated with them too. If this is true, variation in investor attention to concept stocks should be negatively related to investor attention. In the data, however, we find that the level of search interest in "concept stocks" is only weakly and positively correlated with the level of search interest in "financial crisis", with a correlation coefficient of $10 \%$. Furthermore, when considering the change of those two variables, we find that the correlation coefficient is virtually zero. Figures 2 and 3 also show that the strong comovement of the speculative demand with both returns and trading volume exists before the outbreak of the financial crisis. Therefore, any concern over a time-varying effect arising from the financial crisis does not influence our results.

Another potential question is whether the search volume index from Google is representative of investor search interest in China. Indeed, Baidu Inc. has overtaken Google to become the dominant Chinese language search engine in China during our sample period. In 2007, Baidu had a market share of $60.1 \%$ while Google came second with a $25.9 \%$ share. $^{12}$ However, Baidu's search volume index has a shorter sample period (starting from 07/2006) and the data are not freely accessible by the public. Nevertheless Baidu's search volume index can still be viewed online, and the value can be seen when one moves the cursor on the on-line time series plot of Baidu SVI. We manually collected the Baidu SVI for the sample period 07/2006 to $05 / 2014$ by moving the cursor along the time series. Since $06 / 2014$, the Google SVI is 0 , which possibly

\footnotetext{
${ }^{12}$ See the article "Baidu leads China Web search market in Q4" from Reuters, Jan 25, 2008.
} 
reflects a more stringent ban of the Google service in Mainland China by the Chinese government. The Baidu SVI might have a structural shift in our sample due to the fact that Google shut down its search service on the Chinese mainland and shifted its service to Hong Kong on 23 March, 2010.

To make it easier to visualize the relationship between the Google SVI and Baidu SVI, we plot the original level of the two SVIs in two sub-sample periods, 07/2006-12/2010 and 01/2011-05/2014. Figure 4 shows that the co-movement between the original level of the two SVIs is present in both periods. To avoid any concern about non-stationarity, we obtain the correlation between the change in the original level of SVIs. The Spearman rank correlation between the change in the two SVIs is $45 \%, 43 \%$, and $48 \%$ in the whole sample, the sub-sample before March 2010, and the sub-sample after March 2010, respectively.

[Insert Figure 4 about here]

Despite the substantial correlation between Google SVI and Baidu SVI over the whole sample period, we find the relative information content of these SVIs for speculative demand varies over time. Although not tabulated here, the predictive ability of Google SVI for return reversal is stronger before 03/2010 than after, while the Baidu SVI predicts return reversals mainly after 03/2010. This variation in predicability is likely to reflect the declining market share of Google search engine in Mainland China (especially after 03/2010) while Baidu gains its market dominance in recent years.

Another issue that may affect the validity of statistical inference is the predictive variable, SVI, being persistent and correlated with returns. This can bias the coefficient estimate of the predictive regression in a finite sample, leading to the well-known Stambaugh bias (Stambaugh (1999)). To alleviate this concern, we construct a new SVI by taking a similar approach to Da et al. (forthcoming). ${ }^{13}$ We first take the log difference of the level of original SVI, and then regress it on the monthly dummies to remove the seasonality. We retain the residual as the new SVI, denoted as $\Delta S V I^{\perp}$. The logarithm transformation reduces the number of the observations especially in the early part of our sample when the original Google SVI is zero. Similarly, we construct $\Delta S V I^{\perp} \_$Baidu based on Baidu SVI. Untabulated regressions show that $\Delta S V I^{\perp}$, similar to SVI, predicts return reversals in the whole sample. As mentioned above, the relative predictive power of Baidu and Google SVI varies over time, therefore we also run predictive regressions of returns on Google $\Delta S V I^{\perp}$ for the sample between 01/2004 and 03/2010, and for $\Delta S V I^{\perp} \_B a i d u$ for the sample period between 04/2010 and $12 / 2011$.

\footnotetext{
${ }^{13}$ We thank an anonymous referee for this suggestion.
} 
[Insert Table 10 about here]

Panel A in Table 10 shows that the coefficients of the first and the second lag of $\Delta S V I^{\perp}$ are negative. For Shanghai A (Shenzhen A and Shenzhen SME) shares the coefficients are statistically significant at the $5 \%(10 \%)$ level, and insignificant for other shares. These results are consistent with Table 5, lending further support to the findings that the speculative demand predicts return reversals, especially for those markets that are more populated by retail investors. We also report the results based on $\Delta S V I^{\perp} \_$Baidu. Panel B in Table 10 shows that, during the sample period between 04/2010 and 12/2011, $\Delta S V I^{\perp}{ }$ Baidu predicts return reversals. The coefficients of the first lag of $\Delta S V I^{\perp}{ }_{-}$Baidu are negative for all five share indices, and are statistically significant at the $10 \%$ level or lower for four indices, with the only exception being Shenzhen B. The size of the coefficients is larger for Shanghai A, Shenzhen A and Shenzhen SME than for the $\mathrm{B}$ shares. Including more lagged $\Delta S V I^{\perp} \_B a i d u$ does not change our results qualitatively. Overall these findings suggest that our results cannot be attributed to Stambaugh bias.

\section{Conclusions}

We construct a novel proxy of Chinese retail investors' speculative demand from online search interest in "concept stocks", a class of stocks which are related to investment concepts or ideas. Based on the attention theory of Barber and Odean (2008), we argue that our proxy captures the speculative demand of attention-constrained retail investors. We show that this proxy is significantly and positively correlated with trading volume, a widely used measure of speculative trading. In addition, it strongly co-moves with the number of new stock accounts in the Chinese stock markets.

We examine how the speculative demand affects the returns and trading volume of Chinese stock indices from January 2004 to December 2011. We find that: 1) increased speculative demand predicts subsequent reversals of market returns; 2) the small stock premium declines following high levels of speculative demand; 3) the high speculative demand causes lower near-future returns while recent high past returns cause the high speculative demand; 4) the speculative demand explains more variation in subsequent returns of A shares than B shares. Our results strongly support the attention theory of Barber and Odean (2008). 
Figure 1.

Number of Accounts Held by Retail Investors and Institutional Investors

This figure presents the ratio between the number of accounts held by retail investors and the number of accounts held by institutional investors in A-share markets (solid line) and B-Share markets (dash line). The data are provided by China Securities Depository and Clearing Corporation Limited. The sample period spans from 2004 to 2012

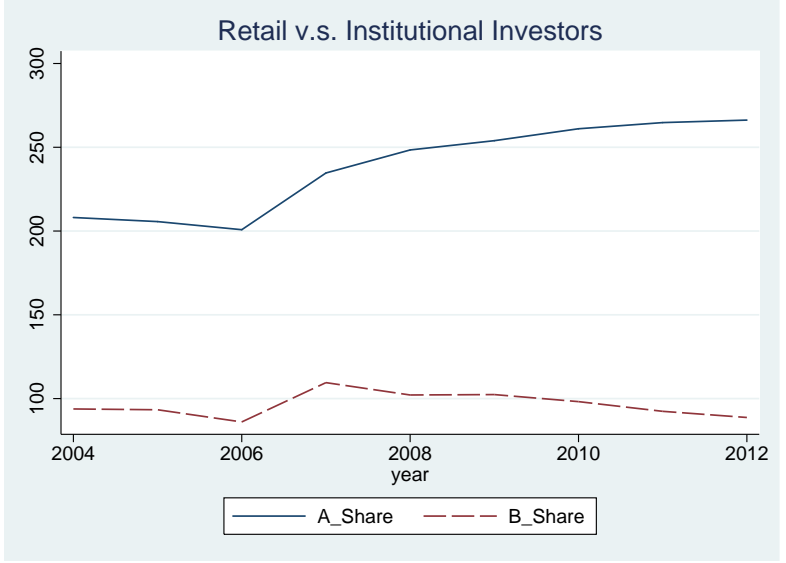


Figure 2. Shanghai A Share Index and Online Search Interest in Concept Stocks

This figure presents the weekly Shanghai A share index and its trading volume together with the search volume index of the key words "concept stocks" provided by Google Insights. The trading volume is in billions of Chinese yuan. The sample spans from 10/01/2004 to 24/12/2011.

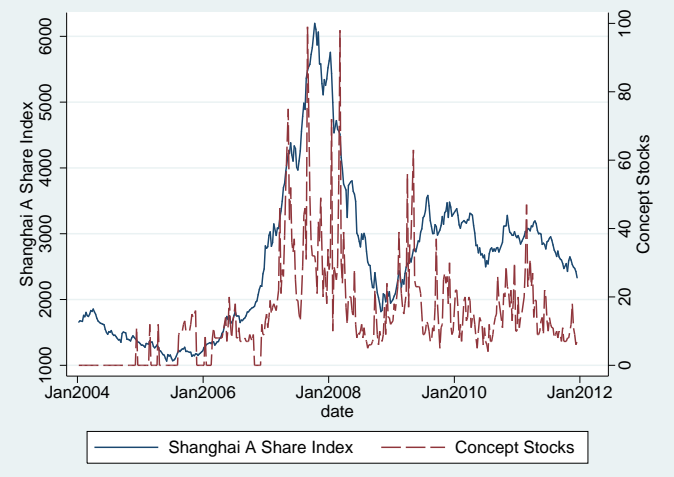

(a) Shanghai A share index

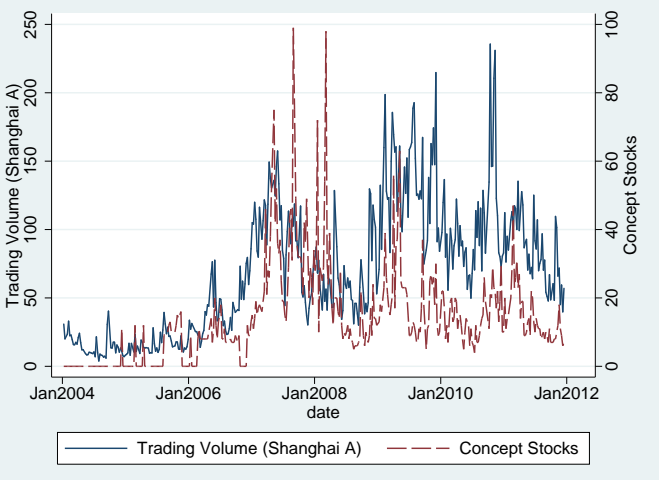

(b) Trading Volume of Shanghai A Shares 
Figure 3. Shenzhen A Share Index and Online Search Interest in Concept Stocks

The figure presents the weekly Shenzhen A share stock index and its trading volume together with the search volume index of the key words "concept stocks" provided by Google Insights. The trading volume is in billions of Chinese yuan. The sample spans from 10/01/2004 to 24/12/2011.

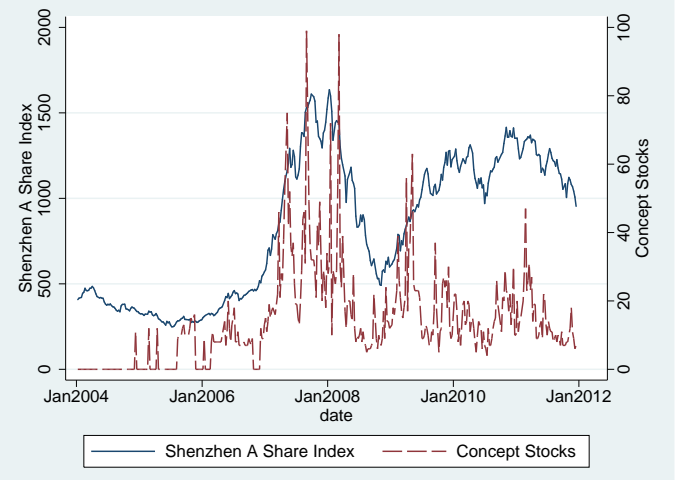

(a) Shenzhen A share index

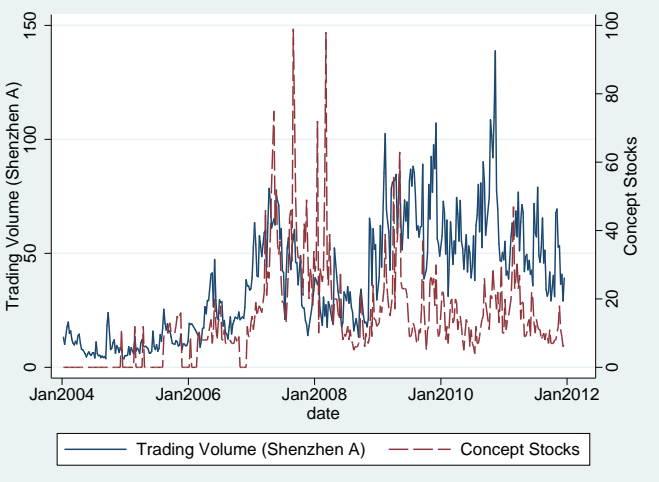

(b) Trading Volume of Shenzhen A Shares 
Table 1.

Summary Statistics of Speculative Demand Variables

This table presents the summary statistics of weekly speculative demand variables. The sample spans from 10/01/2004 to 24/12/2011 (with the exception that Shenzhen SME data are only available from 01/12/2005). "Concept_stock_original" is the search volume index from a search of the phrase "concept stocks" in Chinese on Google. "SVI" is the residual from a linear regression of "Concept_stock_original" on monthly dummies and a search volume index on the keyword "stock" (in Chinese) within mainland China.

\begin{tabular}{lllllll}
\hline & Mean & Std. Dev. & Min. & Max. & Skewness & Kurtosis \\
\hline Concept_stock_original & 13.89 & 14.27 & 0.00 & 99.00 & 2.22 & 10.94 \\
SVI & 0.00 & 10.25 & -66.48 & 65.85 & -0.40 & 17.04 \\
\hline
\end{tabular}


Table 2 .

Summary Statistics of Weekly Returns and Trading Volume

This table presents the summary statistics of weekly returns and trading volume. The sample spans from 10/01/2004 to 24/12/2011 (with the exception that Shenzhen SME data are only available from 01/12/2005).

\begin{tabular}{|c|c|c|c|c|c|c|}
\hline & Mean & Std. Dev. & Min. & Max. & Skewness & Kurtosis \\
\hline & \multicolumn{6}{|c|}{ Panel A: Weekly Return } \\
\hline Shanghai A & 0.09 & 3.93 & -14.92 & 13.93 & 0.03 & 4.35 \\
\hline Shanghai B & 0.17 & 5.27 & -18.17 & 29.19 & 0.45 & 6.80 \\
\hline Shenzhen A & 0.22 & 4.45 & -16.66 & 15.54 & -0.26 & 4.16 \\
\hline Shenzhen B & 0.17 & 4.47 & -15.99 & 19.90 & -0.02 & 4.55 \\
\hline \multirow[t]{2}{*}{ Shenzhen SME } & 0.45 & 4.83 & -16.49 & 17.71 & -0.25 & 4.05 \\
\hline & \multicolumn{6}{|c|}{ Panel B: Weekly Trading Volume } \\
\hline Shanghai A & 345.95 & 240.73 & 25.30 & 1034.94 & 0.58 & 2.56 \\
\hline Shanghai B & 3.13 & 3.33 & 0.28 & 33.17 & 4.60 & 34.09 \\
\hline Shenzhen A & 189.74 & 129.53 & 14.99 & 588.31 & 0.56 & 2.43 \\
\hline Shenzhen B & 3.37 & 2.41 & 0.42 & 17.52 & 2.07 & 9.40 \\
\hline Shenzhen SME & 33.36 & 35.47 & 0.00 & 147.46 & 0.86 & 2.62 \\
\hline
\end{tabular}


Table 3 .

Correlation between the Number of Newly Opened Stock Accounts and Speculative Demand

This table presents the Spearman rank correlation between SVI and the number of newly opened stock accounts, and trading volume. "New_account" is the number of newly opened stock accounts in A share or B share markets. "New_account_change" is the change in "New_account". "turnover_res" is the residual from an $\mathrm{AR}(1)$ regression of trading volume. $* * *, * *, *$ indicate significance at the $1 \%, 5 \%$, and $10 \%$ levels.

\begin{tabular}{l|ccccc}
\hline & Shanghai A Share & Shanghai B Share & Shenzhen A Share & Shenzhen B Share & Shenzhen SME \\
\hline New_account_change & $0.30^{* * * *}$ & $0.20^{* * *}$ & $0.30^{* * *}$ & $0.20^{* * *}$ & - \\
Turnover_res & $0.30^{* * *}$ & $0.15^{* * *}$ & $0.28^{* * *}$ & 0.07 & $0.24^{* * *}$ \\
\hline
\end{tabular}


Table 4.

Contemporaneous Regressions of Trading Volume on Speculative Demand

This table reports contemporaneous regressions of trading volume on speculative demand measured by Google search volume index of concept stocks. "turnover_res" is the residual from an AR(1) regression of trading volume. "L." before a variable means that variable has been lagged by one period. The sample spans from 10/01/2004 to 24/12/2011 (with the exception that Shenzhen SME data are only available from 01/12/2005). Newey-West standard errors are in parentheses.

Significance levels: $\quad *: 10 \% \quad * *: 5 \% \quad * * *: 1 \%$

\begin{tabular}{|c|c|c|c|c|c|}
\hline & Shanghai A Share & Shanghai B Share & Shenzhen A Share & Shenzhen B Share & Shenzhen SME \\
\hline \multirow[t]{2}{*}{ SVI } & $2.190 * * *$ & -0.000 & $1.305 * * *$ & -0.001 & $0.329 * *$ \\
\hline & $(0.753)$ & $(0.001)$ & $(0.460)$ & $(0.004)$ & $(0.140)$ \\
\hline \multirow[t]{2}{*}{ L.return_1 } & $5.620 * * *$ & $0.012^{*}$ & $3.859 * * *$ & $0.032 * * *$ & $0.752 * *$ \\
\hline & (2.039) & $(0.006)$ & $(1.082)$ & $(0.012)$ & $(0.293)$ \\
\hline \multirow[t]{2}{*}{ L.turnover_res } & $-0.189 * *$ & $0.229 * *$ & $-0.187 * *$ & 0.001 & $-0.186^{* *}$ \\
\hline & $(0.083)$ & $(0.106)$ & $(0.090)$ & $(0.143)$ & $(0.089)$ \\
\hline \multirow[t]{2}{*}{ Constant } & -3.999 & -0.003 & -2.853 & -0.022 & 0.611 \\
\hline & $(5.433)$ & $(0.008)$ & (3.401) & $(0.038)$ & (1.448) \\
\hline Adj. R-squared & 0.07 & 0.20 & 0.08 & 0.02 & 0.05 \\
\hline $\mathrm{N}$ & 376 & 376 & 376 & 376 & 283 \\
\hline
\end{tabular}


Table 5 .

Predictive Regressions of Returns and Speculative Demand

This table reports predictive regressions of returns and speculative demand. "return" is the weekly return of the corresponding stock index. "L." ("L2.") before a variable means that variable has been lagged by one (two) period(s). The sample spans from 10/01/2004 to 24/12/2011 (with the exception that Shenzhen SME data are only available from 01/12/2005).

Significance levels : $\quad *: 10 \% \quad * *: 5 \% \quad * * *: 1 \%$

\begin{tabular}{|c|c|c|c|c|c|}
\hline & Shanghai A & Shanghai B & Shenzhen A & Shenzhen B & Shenzhen SME \\
\hline \multirow{2}{*}{ L.SVI } & -0.026 & 0.027 & -0.027 & -0.025 & -0.013 \\
\hline & $(0.017)$ & $(0.039)$ & $(0.021)$ & $(0.025)$ & $(0.022)$ \\
\hline \multirow[t]{2}{*}{ L2.SVI } & $-0.051 * *$ & -0.011 & -0.051 & -0.011 & $-0.057 *$ \\
\hline & $(0.024)$ & $(0.044)$ & $(0.032)$ & $(0.036)$ & $(0.030)$ \\
\hline \multirow[t]{2}{*}{ L.return } & 0.050 & $0.138 * *$ & $0.098 *$ & 0.074 & 0.063 \\
\hline & $(0.050)$ & $(0.069)$ & $(0.056)$ & $(0.053)$ & $(0.065)$ \\
\hline \multirow[t]{2}{*}{ L2.return } & $0.169 * * *$ & 0.002 & $0.121 * *$ & 0.031 & $0.122 *$ \\
\hline & $(0.055)$ & $(0.079)$ & $(0.053)$ & $(0.060)$ & $(0.064)$ \\
\hline \multirow[t]{2}{*}{ Constant } & 0.052 & 0.134 & 0.148 & 0.148 & 0.367 \\
\hline & $(0.201)$ & $(0.273)$ & $(0.232)$ & $(0.239)$ & $(0.302)$ \\
\hline Adj. R-squared & 0.02 & 0.01 & 0.02 & -0.00 & 0.01 \\
\hline $\mathrm{N}$ & 383 & 383 & 383 & 383 & 291 \\
\hline
\end{tabular}


Table 6.

Predictive Regressions of Returns and Speculative Demand with Control Variables

This table reports predictive regressions of returns and speculative demand with control variables. "return" is the weekly return of the corresponding stock index. "L." ("L2.") before a variable means that variable has been lagged by one (two) period(s). The sample spans from 10/01/2004 to 24/12/2011 (with the exception that Shenzhen SME data are only available from 01/12/2005).

Significance levels : $\quad *: 10 \% \quad * *: 5 \% \quad * * *: 1 \%$

\begin{tabular}{|c|c|c|c|c|c|}
\hline & Shanghai A & Shanghai B & Shenzhen A & Shenzhen B & Shenzhen SME \\
\hline \multirow[t]{2}{*}{ L.SVI } & -0.023 & 0.031 & -0.022 & -0.022 & -0.008 \\
\hline & $(0.018)$ & $(0.039)$ & $(0.021)$ & $(0.025)$ & $(0.023)$ \\
\hline \multirow[t]{2}{*}{ L2.SVI } & $-0.050 *$ & -0.010 & -0.049 & -0.010 & $-0.055^{*}$ \\
\hline & $(0.026)$ & $(0.042)$ & $(0.032)$ & $(0.036)$ & $(0.030)$ \\
\hline \multirow[t]{2}{*}{ L.return } & 0.053 & $0.146 * *$ & $0.102 *$ & 0.077 & 0.070 \\
\hline & $(0.052)$ & $(0.070)$ & $(0.056)$ & $(0.057)$ & $(0.063)$ \\
\hline \multirow[t]{2}{*}{ L2.return } & $0.156^{* * * *}$ & -0.011 & $0.107 *$ & 0.021 & $0.105^{*}$ \\
\hline & $(0.058)$ & $(0.080)$ & $(0.056)$ & $(0.060)$ & $(0.064)$ \\
\hline \multirow[t]{2}{*}{ L.cpi } & 0.208 & -0.298 & -0.179 & -0.124 & -0.272 \\
\hline & $(0.600)$ & $(0.826)$ & $(0.701)$ & $(0.722)$ & $(0.917)$ \\
\hline \multirow[t]{2}{*}{ L.m2 } & 0.518 & $0.850 * *$ & 0.634 & 0.498 & $0.820 *$ \\
\hline & $(0.345)$ & $(0.410)$ & $(0.436)$ & $(0.326)$ & $(0.458)$ \\
\hline \multirow[t]{2}{*}{ L.gdp } & 0.008 & 0.047 & 0.007 & -0.095 & 0.022 \\
\hline & $(0.142)$ & $(0.210)$ & $(0.158)$ & $(0.160)$ & $(0.142)$ \\
\hline \multirow[t]{2}{*}{ Constant } & -0.017 & -0.331 & 0.096 & 1.135 & 0.160 \\
\hline & $(1.443)$ & $(2.095)$ & (1.598) & (1.667) & $(1.463)$ \\
\hline Adj. R-squared & 0.02 & 0.02 & 0.02 & -0.00 & 0.01 \\
\hline $\mathrm{N}$ & 373 & 373 & 373 & 373 & 291 \\
\hline
\end{tabular}


Table 7 .

VAR of Returns and Speculative Demand

This table reports VAR regressions of returns and speculative demand. "return" is the weekly return of the corresponding stock index. "L." (“L2.”) before a variable means that variable has been lagged by one (two) period(s). The sample spans from 10/01/2004 to 24/12/2011 (with the exception that Shenzhen SME data are only available from 01/12/2005).

Significance levels : $\quad *: 10 \% \quad * *: 5 \% \quad * * *: 1 \%$

\begin{tabular}{|c|c|c|c|c|c|}
\hline & Shanghai A & Shanghai B & Shenzhen A & Shenzhen B & Shenzhen SME \\
\hline \multicolumn{6}{|l|}{ return } \\
\hline \multirow[t]{2}{*}{ L.return } & 0.050 & $0.138 * * *$ & $0.098 *$ & 0.074 & 0.063 \\
\hline & $(0.052)$ & $(0.052)$ & $(0.052)$ & $(0.052)$ & $(0.060)$ \\
\hline \multirow[t]{2}{*}{ L2.return } & $0.169 * * *$ & 0.002 & $0.121 * *$ & 0.031 & $0.122 * *$ \\
\hline & $(0.052)$ & $(0.051)$ & $(0.052)$ & $(0.052)$ & $(0.060)$ \\
\hline \multirow[t]{2}{*}{ L.SVI } & -0.026 & 0.027 & -0.027 & -0.025 & -0.013 \\
\hline & $(0.021)$ & $(0.028)$ & $(0.024)$ & $(0.024)$ & $(0.027)$ \\
\hline \multirow[t]{2}{*}{ L2.SVI } & $-0.051 * *$ & -0.011 & $-0.051 * *$ & -0.011 & $-0.057 * *$ \\
\hline & $(0.021)$ & $(0.028)$ & $(0.024)$ & $(0.024)$ & $(0.027)$ \\
\hline \multirow[t]{2}{*}{ Constant } & 0.052 & 0.134 & 0.148 & 0.148 & 0.367 \\
\hline & $(0.198)$ & $(0.267)$ & $(0.225)$ & $(0.229)$ & $(0.282)$ \\
\hline R Squared & 0.035 & 0.025 & 0.028 & 0.008 & 0.027 \\
\hline \multicolumn{6}{|l|}{ SVI } \\
\hline \multirow[t]{2}{*}{ L.return } & $0.376^{* * *}$ & 0.116 & $0.344 * * *$ & $0.225 * *$ & $0.351 * * *$ \\
\hline & $(0.123)$ & $(0.092)$ & (0.109) & $(0.107)$ & $(0.130)$ \\
\hline \multirow[t]{2}{*}{ L2.return } & 0.133 & 0.022 & 0.164 & -0.097 & 0.207 \\
\hline & $(0.123)$ & $(0.091)$ & (0.109) & $(0.107)$ & $(0.129)$ \\
\hline \multirow[t]{2}{*}{ L.SVI } & $-0.496 * * *$ & $-0.463 * * *$ & $-0.501 * * *$ & $-0.463 * * *$ & $-0.509 * * *$ \\
\hline & $(0.051)$ & $(0.050)$ & $(0.051)$ & $(0.050)$ & $(0.058)$ \\
\hline \multirow[t]{2}{*}{ L2.SVI } & $-0.273 * * *$ & $-0.256 * * *$ & $-0.281 * * *$ & $-0.239 * * *$ & $-0.296^{* * *}$ \\
\hline & $(0.051)$ & $(0.050)$ & $(0.051)$ & $(0.050)$ & $(0.058)$ \\
\hline \multirow[t]{2}{*}{ Constant } & -0.040 & -0.013 & -0.107 & -0.011 & -0.156 \\
\hline & $(0.468)$ & $(0.473)$ & $(0.467)$ & $(0.472)$ & $(0.608)$ \\
\hline R Squared & 0.205 & 0.187 & 0.210 & 0.194 & 0.215 \\
\hline $\mathrm{N}$ & 383 & 383 & 383 & 383 & 291 \\
\hline
\end{tabular}


Table 8 .

VAR of Returns and Speculative Demand with Macro Controls

This table reports VAR regressions of returns and speculative demand with macro control variables. "return" is the weekly return of the corresponding stock index. "L." ("L2.") before a variable means that variable has been lagged by one (two) period(s). The sample spans from 10/01/2004 to 24/12/2011 (with the exception that Shenzhen SME data are only available from 01/12/2005).

Significance levels: $\quad *: 10 \% \quad * *: 5 \% \quad * * *: 1 \%$

\begin{tabular}{|c|c|c|c|c|c|}
\hline & Shanghai A & Shanghai B & Shenzhen A & Shenzhen B & Shenzhen SME \\
\hline \multicolumn{6}{|l|}{ return } \\
\hline \multirow[t]{2}{*}{ L.return } & 0.039 & $0.145 * * *$ & 0.088 & 0.082 & 0.050 \\
\hline & $(0.054)$ & $(0.054)$ & $(0.054)$ & $(0.054)$ & $(0.062)$ \\
\hline \multirow[t]{2}{*}{ L2.return } & $0.159 * * *$ & -0.018 & $0.110 * *$ & 0.015 & $0.115^{*}$ \\
\hline & $(0.055)$ & $(0.055)$ & $(0.056)$ & $(0.054)$ & $(0.062)$ \\
\hline \multirow[t]{2}{*}{ L.SVI } & -0.023 & 0.031 & -0.025 & -0.022 & -0.011 \\
\hline & $(0.022)$ & $(0.030)$ & $(0.026)$ & $(0.025)$ & $(0.028)$ \\
\hline \multirow[t]{2}{*}{ L2.SVI } & $-0.046 * *$ & -0.004 & $-0.047 *$ & 0.001 & $-0.056 * *$ \\
\hline & $(0.023)$ & $(0.030)$ & $(0.026)$ & $(0.026)$ & $(0.028)$ \\
\hline \multirow[t]{2}{*}{ L.cpi } & 0.056 & -0.504 & -0.350 & -0.264 & -0.575 \\
\hline & $(0.579)$ & $(0.793)$ & $(0.663)$ & $(0.672)$ & $(0.831)$ \\
\hline \multirow[t]{2}{*}{ L.m2 } & $0.620 *$ & $0.957 *$ & $0.743 *$ & 0.564 & $0.999 * *$ \\
\hline & $(0.363)$ & $(0.499)$ & $(0.415)$ & $(0.423)$ & $(0.474)$ \\
\hline \multirow[t]{2}{*}{ L.gdp } & 0.092 & 0.123 & 0.075 & 0.000 & 0.067 \\
\hline & $(0.127)$ & $(0.174)$ & $(0.145)$ & $(0.147)$ & $(0.161)$ \\
\hline \multirow[t]{2}{*}{ Constant } & -0.974 & -1.133 & -0.664 & 0.090 & -0.368 \\
\hline & (1.328) & $(1.824)$ & $(1.516)$ & $(1.544)$ & $(1.718)$ \\
\hline R Squared & 0.041 & 0.035 & 0.035 & 0.015 & 0.043 \\
\hline \multicolumn{6}{|l|}{ SVI_concept_stock } \\
\hline \multirow[t]{2}{*}{ L.return } & $0.371 * * *$ & 0.106 & $0.330 * * *$ & $0.234 * *$ & $0.298 * *$ \\
\hline & $(0.126)$ & $(0.093)$ & $(0.111)$ & $(0.109)$ & $(0.130)$ \\
\hline \multirow[t]{2}{*}{ L2.return } & 0.076 & -0.004 & 0.137 & -0.138 & 0.168 \\
\hline & $(0.128)$ & $(0.094)$ & $(0.113)$ & $(0.109)$ & $(0.132)$ \\
\hline \multirow[t]{2}{*}{ L.SVI_concept_stock } & $-0.491 * * *$ & $-0.459 * * *$ & $-0.498 * * *$ & $-0.457 * * *$ & $-0.499 * * *$ \\
\hline & $(0.052)$ & $(0.051)$ & $(0.052)$ & $(0.051)$ & $(0.059)$ \\
\hline \multirow[t]{2}{*}{ L2.SVI_concept_stock } & $-0.289 * * *$ & $-0.274 * * *$ & $-0.301 * * *$ & $-0.256^{* * *}$ & $-0.312 * * *$ \\
\hline & $(0.053)$ & $(0.052)$ & $(0.052)$ & $(0.051)$ & $(0.060)$ \\
\hline \multirow[t]{2}{*}{ L.cpi } & $3.514 * * *$ & $3.822 * * *$ & $3.332 * *$ & $3.650 * * *$ & $4.551 * * *$ \\
\hline & $(1.348)$ & $(1.359)$ & $(1.348)$ & $(1.354)$ & $(1.754)$ \\
\hline \multirow[t]{2}{*}{ L.m2 } & 0.939 & 1.029 & 0.858 & 1.159 & 0.892 \\
\hline & $(0.845)$ & $(0.855)$ & $(0.844)$ & $(0.851)$ & $(1.001)$ \\
\hline \multirow[t]{2}{*}{ L.gdp } & 0.022 & 0.024 & 0.028 & 0.044 & -0.024 \\
\hline & $(0.295)$ & $(0.298)$ & $(0.294)$ & $(0.296)$ & $(0.341)$ \\
\hline \multirow[t]{2}{*}{ Constant } & -0.110 & -0.128 & -0.245 & -0.312 & 0.208 \\
\hline & $(3.090)$ & $(3.124)$ & (3.083) & (3.109) & (3.628) \\
\hline R Squared & 0.229 & 0.212 & 0.233 & 0.222 & 0.238 \\
\hline $\mathrm{N}$ & 357 & 357 & 357 & 357 & 275 \\
\hline
\end{tabular}


Table 9.

Small Stock Premium and Speculative Demand

This table reports regressions of small stock premium on speculative demand (and macro control variables). "size_ew" is the small stock premium defined as the return difference between the equally-weighted smallest decile size portfolio and the largest decile size portfolio constructed from all stocks included in the Shanghai (Shenzhen) composite stock index. Market return is the weekly return of the Shanghai (Shenzhen) composite stock index. "L." ("L2.") before a variable means that variable has been lagged by one (two) period(s). The sample spans from 10/01/2004 to 24/12/2011.

Significance levels: $\quad *: 10 \% \quad * *: 5 \% \quad * * *: 1 \%$

\begin{tabular}{|c|c|c|c|c|}
\hline & Shanghai & Shanghai & Shenzhen & Shenzhen \\
\hline \multirow[t]{2}{*}{ L.SVI } & -0.002 & -0.004 & 0.019 & 0.020 \\
\hline & $(0.009)$ & $(0.009)$ & $(0.016)$ & $(0.016)$ \\
\hline \multirow[t]{2}{*}{ L2.SVI } & -0.009 & -0.013 & -0.002 & -0.001 \\
\hline & $(0.010)$ & $(0.010)$ & $(0.017)$ & $(0.017)$ \\
\hline \multirow[t]{2}{*}{ L3.SVI } & $-0.020 *$ & $-0.021 * *$ & $-0.032 *$ & $-0.030^{*}$ \\
\hline & $(0.010)$ & $(0.010)$ & $(0.017)$ & $(0.016)$ \\
\hline \multirow[t]{2}{*}{ L4.SVI } & $-0.012 *$ & $-0.013 * *$ & -0.017 & -0.014 \\
\hline & $(0.007)$ & $(0.006)$ & $(0.018)$ & $(0.017)$ \\
\hline \multirow[t]{2}{*}{ Market Return } & & $-0.064 * * *$ & & -0.049 \\
\hline & & $(0.021)$ & & $(0.039)$ \\
\hline \multirow[t]{2}{*}{ L.cpi } & & 0.099 & & -0.540 \\
\hline & & $(0.279)$ & & $(0.411)$ \\
\hline \multirow[t]{2}{*}{ L.m2 } & & 0.018 & & 0.014 \\
\hline & & $(0.125)$ & & $(0.213)$ \\
\hline \multirow[t]{2}{*}{ L.gdp } & & -0.005 & & -0.068 \\
\hline & & $(0.045)$ & & $(0.084)$ \\
\hline \multirow[t]{2}{*}{ L.size_ew } & $0.294 * * *$ & $0.292 * * *$ & 0.050 & 0.048 \\
\hline & $(0.056)$ & $(0.056)$ & $(0.066)$ & $(0.066)$ \\
\hline \multirow[t]{2}{*}{ L2.size_ew } & $0.153 * * *$ & $0.168 * * *$ & $0.115^{* *}$ & $0.112 *$ \\
\hline & $(0.058)$ & $(0.062)$ & $(0.057)$ & $(0.058)$ \\
\hline \multirow[t]{2}{*}{ L3.size_ew } & 0.092 & $0.108 *$ & 0.055 & 0.049 \\
\hline & $(0.062)$ & $(0.062)$ & $(0.052)$ & $(0.051)$ \\
\hline \multirow[t]{2}{*}{ L4.size_ew } & -0.024 & -0.022 & 0.034 & 0.022 \\
\hline & $(0.052)$ & $(0.054)$ & $(0.063)$ & $(0.062)$ \\
\hline \multirow[t]{2}{*}{ Constant } & 0.117 & 0.181 & 0.033 & 0.761 \\
\hline & $(0.083)$ & $(0.461)$ & $(0.159)$ & $(0.889)$ \\
\hline Adj. R-squared & 0.16 & 0.18 & 0.02 & 0.02 \\
\hline $\mathrm{N}$ & 358 & 349 & 333 & 333 \\
\hline
\end{tabular}


Figure 4. Comparison between Google SVI and Baidu SVI

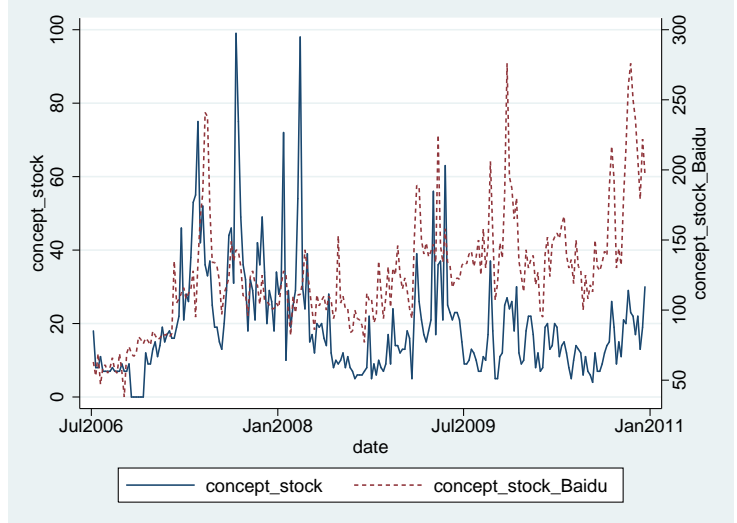

(a) Sample Period: 07/2006-12/2010

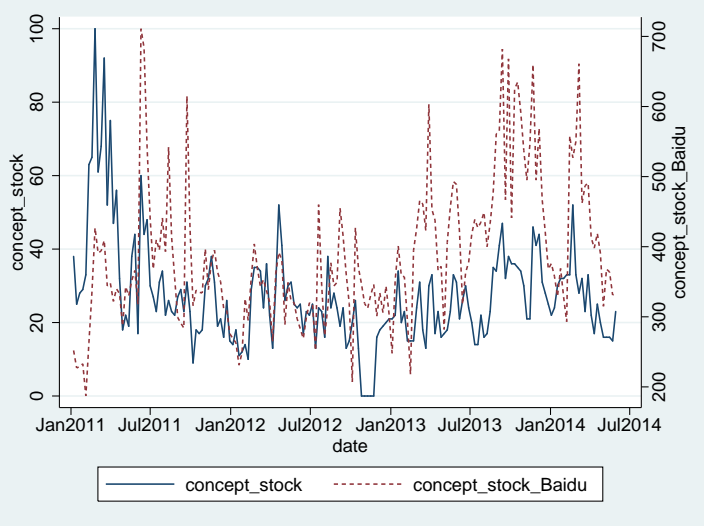

(b) Sample Period: 01/2011-05/2014

The figure presents the Google search volume index together with the Baidu search volume index of the key words "concept stocks" in Chinese within mainland China. Sub-figure (a) plots the SVIs during the sample period of 07/2006-12/2010 and Sub-figure (b) plots the SVIs during the sample period of 01/2011-05/2014. 
Table 10. Predictive Regressions of Returns and the Change in SVI (Logarithm Transformed and Seasonally Adjusted)

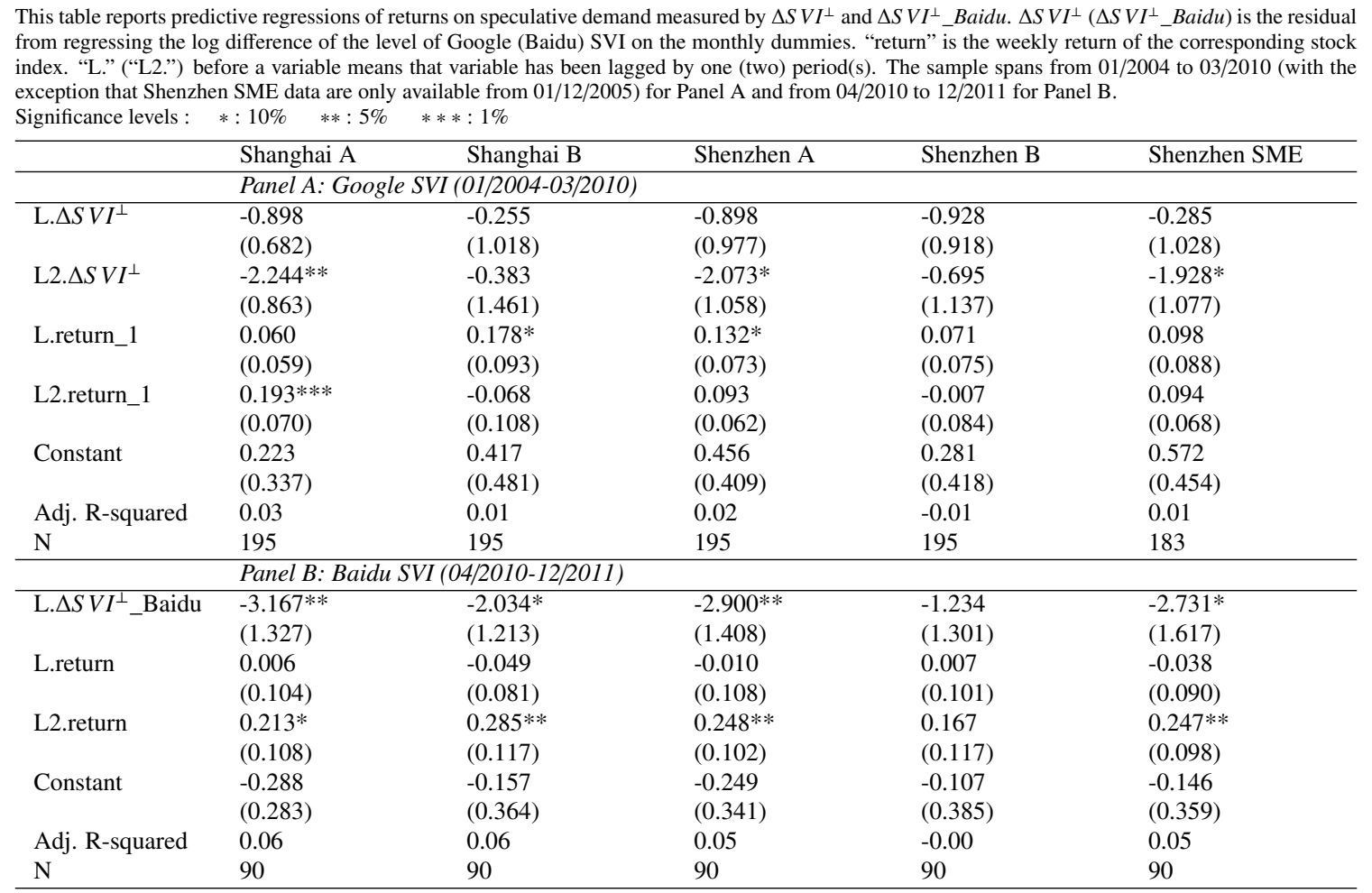




\section{References}

Andrei, D., Hasler, M., 2011. Investors' attention and stock market volatility, Working paper, Swiss Finance Institute .

Bae, K.H., Wang, W., 2012. What's in a "China" name? A test of investor attention hypothesis. Financial Management 41, 429-455.

Baker, M., Wurgler, J., 2006. Investor sentiment and the cross-section of stock returns. Journal of Finance $61,1645-1680$.

Bank, M., Larch, M., Peter, G., 2011. Google search volume and its influence on liquidity and returns of German stocks. Financial Markets and Portfolio Management 25, 239-264.

Barber, B., Odean, T., 2008. All that glitters: The effect of attention and news on the buying behavior of individual and institutional investors. Review of Financial Studies 21, 785-818.

Barber, B., Odean, T., Zhu, N., 2009. Do retail trades move markets? Review of Financial Studies 22, $151-186$.

Bloomfield, R., O'Hara, M., Saar, G., 2009. How noise trading affects markets: An experimental analysis. Review of Financial Studies 22, 2275-2302.

Boulatov, A., Hatch, B., Johnson, S., Lei, A., 2009. Dealer attention, the speed of quote adjustment to information, and net dealer revenue. Journal of Banking \& Finance 33, 1531-1542.

Chan, K., Chen, N., 1991. Structural and return characteristics of small and large firms. Journal of Finance $46,1467-1484$.

Cochrane, J.H., 2001. Asset Pricing. Princeton University Press.

Da, Z., Engelberg, J., Gao, P., 2010. In search of fundamentals, Working paper, University of Notre Dame and University of North Carolina at Chapel Hill .

Da, Z., Engelberg, J., Gao, P., 2011. In search of attention. Journal of Finance 66, 1461-1499.

Da, Z., Engelberg, J., Gao, P., forthcoming. The sum of all fears: Investor sentiment and asset prices. Review of Financial Studies .

Dahlquist, M., Martinez, J.V., 2015. Investor inattention: A hidden cost of choice in pension plans? European Financial Management 21, 1-19.

De Long, J., Shleifer, A., Summers, L., Waldman, R., 1990. Noise traders risk in financial markets. Journal of Political Economy 98, 703-738. 
Deng, X., Gao, L., Jiang, C., 2014. Short sales constraints and stock crash risk: Evidence from a natural experiment. Working Paper, The University of Memphis .

Dorn, D., Huberman, G., 2010. Preferred risk habitat of individual investors. Journal of Financial Economics 97, 155-173.

Drake, M., Roulstone, D., Thornock, J., 2012. Investor information demand: Evidence from Google searches around earnings announcements. Journal of Accounting Research 50, 1001-1040.

Foucault, T., Sraer, D., Thesmar, D., 2011. Individual investors and volatility. Journal of Finance 66, 1369-1406.

Froot, K., Scharfstein, D., Stein, J., 1992. Herd on the street: Informational inefficiencies in a market with short-term speculation. Journal of Finance 47, 1461-84.

Gromb, D., Vayanos, D., 2010. Limits of arbitrage. Annual Review of Financial Economics 2, 251-275.

Han, B., Kumar, A., 2013. Speculative retail trading and asset prices. Journal of Financial and Quantitative Analysis 48, 377-404.

Hirshleifer, D., Lim, S.S., Teoh, S.H., 2011. Limited investor attention and stock market misreactions to accounting information. Review of Asset Pricing Studies 1, 35-73.

Hsieh, J., Walkling, R., 2006. The history and performance of concept stocks. Journal of Banking \& Finance $30,2433-2469$.

Kaniel, R., Saar, G., Titman, S., 2008. Individual investor trading and stock returns. Journal of Finance 63, 273-310.

Kumar, A., 2007. Do the diversification choices of individual investors influence stock returns? Journal of Financial Markets 10, 362-390.

Kumar, A., 2009. Who gambles in the stock market? Journal of Finance 64, 1889-1933.

Kyle, A., 1985. Continuous auctions and insider trading. Econometrica 53, 1315-1335.

Lee, C., Shleifer, A., Thaler, R., 1991. Investor sentiment and the closed-end fund puzzle. Journal of Finance $46,75-109$.

Lemmon, M., Portniaguina, E., 2006. Consumer confidence and asset prices: Some empirical evidence. Review of Financial Studies 19, 1499.

Mei, J., Scheinkman, J., Xiong, W., 2009. Speculative trading and stock prices: Evidence from Chinese AB share premia. Annals of Economics and Finance 10, 225-255. 
Mondria, J., Wu, T., 2012. Asymmetric attention and stock returns, Working paper, University of Toronto .

Peng, L., Xiong, W., 2006. Investor attention, overconfidence and category learning. Journal of Financial Economics 80, 563-602.

Peng, L., Xiong, W., Bollerslev, T., 2007. Investor attention and time-varying comovements. European Financial Management 13, 394-422.

Sharif, S., Anderson, H.D., Marshall, B.R., 2014. Against the tide: The commencement of short selling and margin trading in mainland China. Accounting \& Finance 54, 1319-1355.

Shiller, R., 2005. Irrational Exuberance. Princeton University Press.

Stambaugh, R.F., 1999. Predictive regressions. Journal of Financial Economics 54, 375-421.

Sun, Q., Tong, W., 2000. The effect of market segmentation on stock prices: The China syndrome. Journal of Banking \& Finance 24, 1875-1902.

Vlastakis, N., Markellos, R., 2012. Information demand and stock market volatility. Journal of Banking \& Finance 36, 1808-1821. 